ACTA UNIVERSITATIS LODZIENSIS

FOLIA LITTERARIA POLONICA 2(32) 2016

http://dx.doi.org/10.18778/1505-9057.32.14

Karolina Dobrosz-Michiewicz*

\title{
Struktura wieloznaczności poznawczej (na podstawie komunikowania w polityce)
}

\section{Wieloznaczność w procesie komunikowania}

Postrzeganie komunikacji międzyludzkiej w kategoriach intencjonalnej wymiany zamiarów i informacji, rządzącej się maksymami: ilości, jakości, relacji i sposobu, jak i zakusy pragmatyków komunikacji1 ${ }^{1}$ chcących widzieć dynamiczny proces poznawczy kodowania i dekodowania sensów, jakim jest komunikacja, w kategoriach spełniania lub nie zewnętrznych wobec jednostki zasad komunikacji, w największym stopniu są odpowiedzialne za myślenie o wieloznaczności w kategoriach przekroczenia zasad dobrej konwersacji.

Dopiero przyjęcie kognitywnego punktu widzenia w badaniu i opisie polisemii zasadniczo zmienia optykę. Postrzeganie i przetwarzanie informacji uwzględnia obróbkę nie tylko danych zmysłowych, ale także treści pamięciowych czy wyobrażeń. $Z$ tego względu kategoryzacja sama w sobie jest $\mathrm{z}$ natury polisemiczna, tak jak polisemiczne jest nasze myślenie, a w konsekwencji również komunikowanie ${ }^{2}$. Ten sam egzemplarz może być raz skategoryzowany jako należący do A, innym razem - jako należący do Z, np. w zależności od wpływu kategorii uprzednio aktywowanych ${ }^{3}$. Wieloznaczność widziana z perspektywy własności procesów kategoryzacji komunikujących się nadawcy i odbiorcy (nie zaś w kategoriach immanentnej, najczęściej językowej własności komunikatu) przestaje być jedynie prostym przekroczeniem maksym sposobu i ilości,

\footnotetext{
*Mgr, e-mail: karolinadobrosz@wp.pl; Uniwersytet Łódzki, Wydział Filologiczny, Katedra Dziennikarstwa i Komunikacji Społecznej; ul. Pomorska 171/173, 90-236 Łódź. Artykuł powstał w ramach projektu badawczego finansowanego z dotacji dla młodych naukowców w r. 2015.

${ }^{1}$ Por. A.C. Graeser, K.K. Millis, R.A. Zwaan, Discourse comprehension, „Annual Review of Psychology" 1997, 48. Zdaniem autorów osiągnięcie celu rozmowy możliwe jest jedynie wówczas, jeśli obie zaangażowane w nią strony postępują według określonych, normatywnych zasad „dobrej komunikacji”, tzw. maksym i submaksym, na których powinna opierać się organizacja procesu konwersacji.

${ }^{2}$ Rozumiane w tym przypadku jako wykonanie złożonego zadania poznawczego.

${ }^{3}$ Szerzej o wpływie primingu na procesy percepcji i przetwarzania informacji można przeczytać np. w T. Maruszewski, Psychologia poznania, GWP, Gdańsk 2001.
} 
wyjątkiem od zasad właściwie zorganizowanego procesu konwersacji, a staje się komunikacyjną regułą ${ }^{4}$.

Komunikowanie polityków cechuje szczególna świadomość korzyści płynących z wieloznacznego charakteru procesów przetwarzania informacji. Przeprowadzone przez Petera Bulla analizy wywiadów telewizyjnych z politykami brytyjskimi z lat 1987-1997 wskazują jednoznacznie, iż wśród wszystkich udzielanych przez nich odpowiedzi mniej niż połowę stanowiły wypowiedzi jednoznaczne i wprost. Zarówno Margaret Thatcher, jak i jej główny przeciwnik z Partii Pracy - Neil Kinnock - podczas wyborów w 1987 roku odpowiedzieli wprost na nieco poniżej 40\% pytań (odpowiednio 37\% i 39\%). Mimo iż podczas kolejnych wyborów część uczestników wywiadów zmieniła się, bez zmian pozostały wskaźniki unikania wypowiedzi jasnych i konkretnych (John Major - premier i lider Partii Konserwatywnej odpowiedział wprost jedynie na 40\% pytań, Neil Kinnock - na 51\%, zaś lider Liberalnych Demokratów - Paddy Ashdown - na $63 \%$ pytań). Co więcej, wypowiedzi wieloznaczne stanowiły aż $71 \%$ wszystkich odpowiedzi Tony'ego Blaira w udzielonych przez niego w wywiadach przed wyborami w roku 1997. Dla porównania - analiza wywiadu Martina Bashira z księżną Dianą wykazała, że w jej przypadku dziennikarz uzyskał jasną odpowiedź na 78\% pytań, które zadał, zaś Jon Snow prowadzący wywiad z Moniką Lewinsky uzyskał konkretną odpowiedź aż w przypadku 89\% pytań6. Co stoi za tak silną preferencją wieloznaczności w komunikowaniu polityków? Zapewne strategiczne i wizerunkowe korzyści wynikające z komunikowania wieloznacznego, zwłaszcza jeśli przekaz polityczny docierać ma do różnych grup elektoratu, a każdy odbiorca ma w nim znaleźć coś dla siebie.

Przesunięcie punktu ciężkości w myśleniu o wieloznaczności z komunikatu na komunikację niesie ze sobą konkretne, pragmatyczne skutki. Jeśli bowiem granice wieloznaczności poznawczej wyznaczone są jedynie granicami poznania, oznacza to, że zarówno nadawca, jak i odbiorca mają niemal nieograniczoną swobodę interpretacyjną w kodowaniu i dekodowaniu sensów w komunikacji. Jak więc możliwa jest komunikacja? Czy w jakikolwiek sposób jej powodzenie zależy od nasilenia wieloznaczności? Jak wieloznaczność manifestowana jest w komunikacji?

${ }^{4}$ Dla podkreślenia powyższego, w ramach niniejszej pracy, posługiwać się będę terminem WIELOZNACZNOŚĆ POZNAWCZA.

${ }^{5}$ Zob. P. Bull, Slippery politicians?, „The Psychologist” 2003, No. 16 (11).

${ }^{6} \mathrm{Za}$ : W. Cwalina, Wieloznaczność poznawcza w komunikacji, [w:] Psychologia poznawcza w praktyce. Ekonomia, biznes, polityka, red. A. Falkowski, T. Zaleśkiewicz, PWN, Warszawa 2012. 


\section{Przyjęta optyka badawcza, uzyskane wyniki oraz wnioski z analizy ${ }^{7}$}

Odpowiedzi na powyższe pytania poszukiwać będę w drodze kognitywnej analizy kategorialnej tekstowych emanacji wieloznaczności, prowadzonej w myśl założeń semantyki Gillesa Fauconniera i Marka Turnera oraz gramatyki Ronalda Langackera ${ }^{8}$, na materiale z zakresu komunikowania polityków ${ }^{9}$. Wybór exposé jako potencjalnego źródła poddawanych analizie kategorii wprost wynika z programowego charakteru tego typu wystąpienia, w którym definiuje się cele lub identyfikuje problemy (kategorie) oraz określa sposoby ich realizacji lub niwelowania (egzemplarze kategorii) ${ }^{10}$. I choć $\mathrm{w}$ ramach niniejszego artykułu zestawione zostały pojęcia pochodzące $\mathrm{z}$ exposé premierów wywodzących się z dwóch różnych opcji politycznych (analizie poddano stenogramy wystąpienia Ewy Kopacz

${ }^{7}$ Zestawienie wyodrębnionych w ramach analizy materiału tekstowego kategorii (wskazanie centrum oraz zakresu) przedstawione zostało w formie tabeli i zamieszczone na końcu artykułu.

${ }^{8} \mathrm{Na}$ gruncie psychologii eksperymentalnej za pionierskie w zakresie badania struktury kategorii i natury procesów kategoryzacji mentalnej uznaje się eksperymenty amerykańskiej psycholog Eleanor Rosch, których wyniki zakwestionowały zasadność klasycznego modelu opisu kategorii pojęciowych, zakładającego istnienie pomiędzy pojęciami nieprzekraczalnych granic, zaś w ramach kategorii każdy element za jej równoprawnego reprezentanta. Eksperymenty Rosch dowiodły, iż w większości przypadków ludzki umysł porządkuje świat w oparciu o zupełnie inne mechanizmy. Większość osób biorących udział w eksperymentach badaczki była bowiem skłonna uznać „,jabłko”, a nie „orzech” za lepszego reprezentanta kategorii OWOCE. Podobnie „gołębia” postrzegano jako bardziej reprezentatywnego dla kategorii PTAK, aniżeli „strusia” czy „pingwina". Wobec powyższego konieczne stało się wypracowanie takiego opisu systemu pojęciowego, który zakładałby radialną strukturę pojęć - istnieje centralny, dający się wyróżnić element, stanowiący prototyp danej kategorii, zaś pozostałe elementy włącza się w zakres pojęcia na podstawie podobieństwa do przedstawiciela prototypowego. W zależności od odległości od „centrum” możliwe jest również określenie stopnia przynależności do danego zbioru. Wprowadzona tym samym skalarność systemu pojęciowego, w przeciwieństwie do modelu opartego na opozycjach binarnych, wydaje się lepiej oddawać ciągłą naturę postrzeganych zjawisk otaczającego nas świata. Drugim ważnym odkryciem Rosch było wyróżnienie poziomu podstawowego, który - jak to trafnie ujmuje Maria Indyk - ,posiada swą uprzywilejowaną, specyficzną pozycję w ramach pionowego uszeregowania poziomów kategoryzacji”. Oznacza to, iż np. PIES stanowi kategorię poziomu podstawowego w odróżnieniu od bardziej ogólnej ZWIERZĘ czy bardziej szczegółowej JAMNIK. Opierając się na wprowadzonych przez Rosch pojęciach prototypu i poziomu podstawowego amerykański językoznawca George Lakoff zaproponował nowe ujęcie jednostek semantycznych i nowy sposób ich badania. Włączenie w zakres analizy procesu znaczeniotwórczego pomijanego dotąd aspektu psychologicznego - reguł percepcji, doświadczenia, wiedzy i wyobraźni nadawcy i odbiorcy - oznaczało odrzucenie założenia o istnieniu tzw. właściwych znaczeń, przyjęciu tezy o mętności myślenia i stapianiu jako właściwości myślenia odpowiedzialnej za procesy kategoryzacji, zarówno w zakresie rozpoznania, jak i kreacyjności. Wieloznaczne są więc z natury metafora i metonimia, funkcjonujące $\mathrm{w}$ naszym umyśle w oparciu o zasadę amalgamatyczności, zaś metaforyczne - kategorie naszego powszedniego myślenia.

${ }^{9} \mathrm{~W}$ związku z cechującą komunikowanie polityków preferencją wieloznaczności.

${ }^{10}$ Por. ustęp 2 art. 154 Konstytucji Rzeczypospolitej Polskiej z dnia 2 kwietnia 1997 roku. 
z 1 października 2014 roku $^{11}$ oraz Beaty Szydło z 18 listopada 2015 roku $^{12}$ ), jedynym celem autorki było ujawnienie możliwie wielu emanacji wieloznaczności i na ich podstawie wnioskowanie o jej naturze, nie zaś rozważanie zasadności bądź etycznych aspektów komunikowania poprzez wieloznaczność w polityce (interpretację powyższego pozostawiono socjologom, politologom i specjalistom od marketingu politycznego).

Wyniki przeprowadzonych analiz wydają się prowadzić zasadniczo do trzech następujących wniosków:

1. Wieloznaczność rozumiana jako operowanie polisemicznymi kategoriami uobecniona jest w obu analizowanych komunikatach, choć występuje w nich w różnym natężeniu. W przemówieniu Kopacz dominują (11 z 14: SUKCES NASZEGO KRAJU, DOBROBYT POLSKI, POLITYKA ZAGRANICZNA, BEZPIECZEŃSTWO, FINANSE PUBLICZNE, ZDROWA GOSPODARKA, KRYZYS DEMOGRAFICZNY, ROZWÓJ NAUKI, POTENCJAŁ MORZA, REWOLUCJA CYFROWA, KULTURA) monosemiczne kategorie z jednym, wyraźnym centrum i skoncentrowanymi wokół niego egzemplarzami, podczas gdy w przemówieniu Szydło, wśród kategorii dla których udało się wyodrębnić pary: centrum oraz egzemplarze kategorii (10), sześć stanowią kategorie polisemiczne (z więcej niż jednym centrum kategorii i radialną strukturą: ZMIANA, KAPITAŁ, WYZWANIA, BEZPIECZEŃSTWO, RODZINA, SPRAWIEDLIWOŚĆ). W tym sensie, wieloznaczność poznawcza stanowi naturalny komponent każdej komunikacji - wprost wynikający z własności procesów kategoryzacji - na pewnym podstawowym poziomie: struktury kategorii, które same w sobie mogą być monosemiczne lub polisemiczne.

2.W toku analizy kategorialnej przemówienia Beaty $\mathrm{Szydło}^{13}$ zaobserwowano występowanie $\mathrm{w}$ tekście polisemicznych $\mathrm{z}$ natury amalgamatów konceptualnych (3: DOBRA ZMIANA, AKTYWIZACJA WIELKIEJ REZERWY, WYZWANIA PRZYSZŁOŚCI), powstałych w wyniku stopienia kategorii, których zakres został jedynie częściowo zdefiniowany (znamy zakres kategorii w przestrzeni wyjściowej 1: ZMIANA, WIELKIE REZERWY i WYZWANIA, zaś nie znamy zakresu kategorii w przestrzeni wyjściowej 2: DOBRA, AKTYWIZACJA oraz PRZYSZŁOŚĆ). Wraz z rozszerzaniem się interpretacyjnego marginesu rośnie poziom wieloznaczności. Zatem w przypadku amalgamatów mamy do czynienia $\mathrm{z}$ wieloznacznością drugiego poziomu.

3. Co więcej, jeżeli mamy do czynienia z sytuacją, w której amalgamaty konceptualne powstają $\mathrm{w}$ wyniku rzutowania do przestrzeni generycznej zakre-

\footnotetext{
${ }^{11}$ Stenogram dostępny jest pod adresem https://www.premier.gov.pl/realizacja-planow/expose-premier-ewy-kopacz-stenogram.html [dostęp: 1.03.2016].

${ }^{12}$ Stenogram dostępny jest pod adresem https://www.premier.gov.pl/expose-premier-beaty-szydlo-stenogram.html [1.03.2016].

${ }^{13}$ Nie zaobserwowano występowania tego typu stopień w exposé Ewy Kopacz.
} 
su kategorii polisemicznych (zarówno ZMIANA, WIELKIE REZERWY, jak i WYZWANIA to kategorie polisemiczne) lub w wyniku rzutowania kategorii, których zakres nie został w żaden sposób w komunikacji dookreślony (jak to ma miejsce w przypadku uobecnionych w tekście kategorii: WIELKI PLAN INWESTYCYJNY, RZECZYWISTY PRZEŁOM, GŁĘBOKA PRZEBUDOWA, PROJEKT NAPRAWY PAŃSTWA, dla których nie wskazano żadnych egzemplarzy), margines interpretacyjny rozszerza się jeszcze bardziej. W takim przypadku możemy mówić o tzw. wieloznaczności wyższego rzędu ${ }^{14}$.

Zatem wieloznaczność poznawcza może być uobecniana w komunikacji wielostopniowo: na poziomie podstawowym (wynikającym z polisemicznej natury pojęć, mających więcej niż jedno centrum i radialną strukturę, ale raczej dookreślony zakres; rola kreacyjności odbiorcy w przetwarzaniu informacji jest owym zakresem zawężona), drugiego poziomu (w konsekwencji polisemicznej natury amalgamatów powstających ze stopienia kategorii; zakres może być znany częściowo, dlatego rola kreacyjności odbiorcy w przetwarzaniu informacji rozszerza się) oraz wieloznacznością wyższego rzędu (operowaniem amalgamatami powstałymi ze stopienia polisemicznych kategorii lub kategorii, których zakres nie jest znany - wówczas rola kreacyjności odbiorcy w przetwarzaniu informacji jest ograniczona jedynie granicami jego percepcji).

\section{Wieloznaczność poziomu podstawowego: polisemiczne kategorie}

W gramatyce kognitywnej Langackera rozpoznanie, czyli postrzegane podobieństwo między dwoma kategoriami językowymi, leży u podstaw dwóch typów relacji kategoryzujących: konkretyzacji (elaboration) i rozszerzenia (semantic extension). Dokonując operacji przyporządkowania konkretnego egzemplarza do kategorii, albo sytuujemy go na kontinuum pomiędzy biegunem hiponimicznym i hiperonimicznym w zależności od podobieństwa do egzemplarza typowego (konkretyzacja), jeśli atrybuty obu pokrywają się, albo - kiedy pokrywają się jedynie częściowo - kategorię rozszerzamy. Możemy więc powiedzieć, że kategoryzujemy egzemplarze ŚCIENNA, KORKOWA, METALOWA poprzez ich konkretyzację do kategorii TABLICA, zaś TABLICA MENDELEJEWA - poprzez jej rozszerzenie. Wyabstrahowany w umyśle (ze wszystkich egzemplarzy kategorii) schemat TABLICY sankcjonuje zarówno prototyp kategorii wraz z jej konkretyzacjami (pionowo i poziomo uszeregowanymi: TABLICA ŚCIENNA, tj. TABLICA ŚCIENNA KORKOWA, TABLICA

\footnotetext{
${ }^{14} \mathrm{Nie}$ zaobserwowano występowania tak rozumianej wieloznaczności, tj. wieloznaczności wyższego rzędu, w exposé Ewy Kopacz.
} 
ŚCIENNA METALOWA itd.), jak i rozszerzeniami (TABLICA MENDELEJEWA) znacząco różniące się od prototypu. Zarówno w przypadku konkretyzacji, jak i rozszerzenia mamy do czynienia z postrzeganym podobieństwem między kategoriami - zarówno TABLICA KORKOWA, jak i TABLICA MENDELEJEWA postrzegane są jako podobne, przy czym oczywiście TABLICA KORKOWA wykazuje większy stopień podobieństwa do prototypowej TABLICY niż TABLICA MENDELEJEWA ${ }^{15}$.

Czy to zróżnicowanie podobieństwa wpływa na rozpoznanie przynależności egzemplarzy do poszczególnych kategorii? Zdaniem Johna Taylora (1995/2001) w przypadku kategorii monosemicznych, takich jak TABLICA istotą rozpoznania jest konkretyzacja oparta na zasadzie prototypowej organizacji pojęć, podczas gdy znaczenia kategorii polisemicznych, takich jak np. SZKOŁA - podlegają zasadzie podobieństwa rodzinnego ${ }^{16}$. O ile więc pojęcia monosemiczne skupione są zawsze wokół jednego centrum, ogniskującego konkretyzacje i rozszerzenia kategorii (jak w przypadku opisanej powyżej kategorii TABLICA), pojęcia polisemiczne tworzą tzw. sieci radialne, o odrębnych, choć pokrewnych pojęciowych centrach (kategoria dwojga centrum: SZKOŁA jako BUDYNEK oraz SZKOŁA jako INSTYTUCJA wraz z jej egzemplarzami: UCZNIOWIE, LEKCJE; KIERUNEK W SZTUCE, LITERATURZE, FILOZOFII, OPINIA; ZMUSZANIE KOGOŚ DO WYSIŁKU itd.).

Struktura definiowanych pojęć znacząco różnicuje przemówienia Ewy Kopacz i Beaty Szydło. W przemówieniu Kopacz poszczególne pojęcia zwykle widziane są przez pryzmat jednego centrum (DOBROBYT POLSKI to 400 MILIARDÓW ZŁOTYCH W NOWEJ PERSPEKTYWIE FINANSOWEJ, FINANSE PUBLICZE to gospodarowanie PODATKAMI, a WALKA Z KRYZYSEM DEMOGRAFICZNYM oznacza działania w obszarze wsparcia OPIEKI NAD DZIEĆMI), wokół którego koncentrycznie rozmieszczone są poszczególne egzemplarze (OPIEKA NAD DZIEĆMI: NAKŁADY NA BUDOWĘ ŻŁOBKÓW, ŚWIADCZENIA RODZICIELSKIE, ULGI W CIT DLA PRZEDSIĘBIORCÓW ZAKŁADAJĄCYCH PRZYZAKŁADOWE ŻŁOBKI I PRZED-

\footnotetext{
${ }^{15}$ Za: H. Kardela, (Nie)podobieństwo w morfologii. Amalgamaty kognitywne, [w:] Kognitywistyka. Podobieństwo, red. H. Kardela, Z. Muszyński, M. Rajewski, Wydawnictwo UMCS, Lublin 2006.

${ }^{16} \mathrm{Na}$ wiele wątpliwości w zakresie zasadności klasycznej koncepcji pojęć wskazywał już w Dociekaniach filozoficznych Ludwig Wittgenstein. Podjąwszy próbę zdefiniowania pojęcia Spiel (GRA) zauważył, iż różne elementy tej kategorii nie posiadają wspólnego im wszystkim zbioru właściwości, na podstawie których można by jasno stwierdzić, co jest grą, a co nią nie jest. Granice tej kategorii są więc rozmyte - co jednak nie umniejsza jej przydatności do celów komunikacyjnych. Wittgenstein zauważył bowiem, iż kategoria GRA nie jest zbudowana na zasadzie wspólnych cech definicyjnych, tak jak chciałby tego Arystoteles, lecz na zasadzie siatki krzyżujących się podobieństw, analogicznie do podobieństwa wszystkich członków rodziny. Niektóre atrybuty pewnych elementów tej kategorii są wspólne z innymi, niektóre zaś nie. Nie istnieje jednak żadna pula cech wspólnych dla wszystkich elementów tej kategorii, a więc - w myśl koncepcji klasycznej - zbiór tzw. cech definicyjnych gry.
} 
SZKOLA, ZASADA ZŁOTÓWKA ZA ZŁOTÓWKĘ), w przemówieniu Szydło mamy do czynienia raczej z więcej niż jednym centrum danej kategorii (SPRAWIEDLIWOŚĆ to zarówno SYSTEM SĄDOWNICTWA, jak i sprawiedliwość społeczna, tj. WYRÓWNYWANIE SZANS, zaś wśród egzemplarzy kategorii SPRAWIEDLIWOŚĆ znajdziemy zarówno: NISKĄ EFEKTYWNOŚĆ i KOPRUPCJĘ W SĄDACH, jak i REWITALIZACJĘ MIAST czy WYRÓWNANIE DOPŁAT DLA ROLNIKÓW DO POZIOMU UE) $)^{17}$.

\section{Wieloznaczność poziomu drugiego oraz wieloznaczność wyższego rzędu: polisemiczne amalgamaty konceptualne}

Mechanizmem odpowiedzialnym za tworzenie nowych sensów, w myśl kognitywnej semantyki Fauconniera i Turnera, jest proces amalgamacji (blending) przestrzeni mentalnych - „konceptualnych pojemników (packets), które konstruujemy podczas myślenia i mówienia dla celów doraźnego (local) rozumienia sytuacji oraz działania"18. W wyniku rzutowania międzyprzestrzennego (cross-space mapping) odpowiadające sobie elementy przestrzeni na wejściu (input spaces) ulegają związaniu: poprzez rzutowanie najpierw w tzw. przestrzeń generyczną (nałożenie na dwie przestrzenie wyjściowe tego, co jest im wspólne), a następnie poprzez dodanie nowych, nieobecnych na wejściu struktur. Powstająca w ten sposób nowa jakość - amalgamat konceptualny (blend), choć co do zasady operuje treściami dostępnymi poznaniu (w rozumieniu jednostkowym), jednocześnie może wykraczać i wykracza poza to, co znane. $Z$ tego również względu te same przestrzenie na wejściu, zdaniem Fauconniera i Turnera, prowadzić mogą do powstania różnych amalgamatów, w zależności od „scenariusza” przywołanego przez poznający umysł $\mathrm{w}$ procesie kategoryzowania ${ }^{19}$. Z natury rzeczy amalgamaty są więc strukturami silnie polisemicznymi. Jeśli dodatkowo powstają $\mathrm{w}$ wyniku rzutowania do przestrzeni generycznej zakresu polisemicznych kategorii lub gdy powstają w wyniku rzutowania kategorii, których zakres

${ }^{17}$ Jest obserwacją marginalną, acz interesującą, że o ile BEZPIECZEŃSTWO w ujęciu Kopacz jest pojęciem monosemicznym, którego egzemplarze (WYDATKI NA OBRONNOŚĆ, NOWOCZESNY SPRZĘT DLA WOJSKA, KONSOLIDACJA PRZEMYSŁU ZBROJENIOWEGO, CENTRUM WETERANA) skupione są wokół jednego centrum (WOJSKO), w ujęciu Szydło - jest pojęciem polisemicznym (w kategoriach bezpieczeństwa rozumie się BEZPIECZEŃSWTO MILITARNE, BEZPIECZEŃSTWO ENERGETYCZNE i POLITYKĘ ZAGRANICZNA ).

${ }^{18}$ G. Fauconnier, M. Turner, Tworzenie amalgamatów jako jeden z głównych procesów w gramatyce, tłum. W. Kubasiński, D. Stanulewicz, [w:] Językoznawstwo kognitywne II. Zjawiska pragmatyczne, red. Kubasiński, D. Stanulewicz, Gdańsk 2001, s. 40.

${ }^{19}$ Por. H. Kardela, dz. cyt., s. 200. 
nie został w żaden sposób w komunikacji uobecniony - mamy do czynienia z tzw. wieloznacznością wyższego rzędu.

Amalgamat DOBRA ZMIANA powstaje z rzutowania w przestrzeń generyczną zawartości przestrzeni wyjściowej 1: ZMIANA (której zakres wskazany został w exposé: zmiana w SPOSOBIE SPRAWOWANIA WŁADZY - „koniec z pychą i arogancją", zmiana w ORGANIZACJI PRACY RZĄDU - poprzez powołanie nowych ministerstw - jak i zmiana DOTYCHCZASOWEJ POLITY$\mathrm{KI})$. Zakres kategorii w przestrzeni wyjściowej 2: DOBRA nie został wskazany w ogóle (co jest DOBRE staje się zależne od jednostkowych danych mentalnych; inaczej mówiąc - dla każdego DOBRE oznaczać może coś innego). Podobnie rzecz ma się z amalgamatem AKTYWIZACJA WIELKIEJ REZERWY, powstałym w wyniku rzutowania zawartości kategorii przestrzeni wyjściowej 1: WIELKA REZERWA, której centrum stanowi: KAPITAŁ FINANSOWY, ale również NIEWYKORZYSTANY POTENCJAŁ INTELEKTUALNY POLAKÓW, oraz zawartości kategorii w przestrzeni wyjściowej 2: AKTYWIZACJA (w jaki sposób ów KAPITAŁ i POTENCJAŁ będą AKTYWIZOWANE definiowane jest jednostkowo). Ponieważ granice kategorii DOBRA oraz AKTYWIZACJI nie zostały w żaden sposób dookreślone - o przynależności egzemplarzy każdorazowo decydować będzie wynik jednostkowego i zindywidualizowanego procesu interpretacyjnego.

Margines interpretacyjny rozszerza się jeszcze bardziej - a w zasadzie otwiera - w przypadku amalgamatów, dla których nie został wskazany zakres kategorii w żadnej z przestrzeni wyjściowych: czym jest więc PROJEKT NAPRAWY? Czy w przypadku PAŃSTWA chodzi o instytucję, czy może o obywateli? Jak GŁĘBOKA będzie PRZEBUDOWA i co będzie przebudowywane? PRZEŁOM w czym? Co oznacza RZECZYWISTY? Jak WIELKI będzie PLAN INWESTYCYJNY i w co będziemy inwestować? W sytuacji, w której komponowanie sensu jest procesem dokonującym się wyłącznie po stronie nadawcy i/lub odbiorcy, w zupełności zależąc od jego kreacyjności, pamięci i wyobraźni, mamy do czynienia z tzw. wieloznacznością wyższego rzędu.

Czy dla poznającego umysłu wielopoziomowa wieloznaczność stanowić może barierę utrudniającą procesy kategoryzacji? Co wyznacza granice polisemii? Zdaniem Langackera „nasze mentalne doświadczenie jest zawsze spójne, ponieważ to my narzucamy na nie strukturę [...]"20. Jedyną granicą polisemii byłyby z tego punktu widzenia granice ludzkiego poznania. Badacz zauważa:

Podstawowym elementem zdolności strukturyzowania jest interpretacja nowego doświadczenia w oparciu o istniejące już doświadczenie, które ujmuje w kategoriach asymetrii między standardem porównania (standard of comparison) a celem porów-

${ }^{20}$ Cyt. za: tamże, s. 195. 
nania (target of comparison) [...] Nasze dotychczasowe doświadczenie przybiera formę mentalnie osadzonej ścieżki (well entrenched) aktywowanej w procesie strukturyzowania konkretnych spostrzeżeń (np. w wypadku rozpoznawania [recognition] konkretnego kształtu)"21.

Zatem z punktu widzenia przetwarzania poznawczego na wieloznaczności, nawet wielopoziomowej, nie tracimy. Czy i co zyskujemy?

\section{O kilku funkcjonalnych ograniczeniach komunikacji opartej na wieloznaczności}

Zdaniem Benjamina I. Page'a, twórcy teorii alokacji nacisku w polityce (emphasis allocation theory of political ambiguity), komunikaty upubliczniane przez polityków z założenia nie są ani jasne, ani konkretne. Wieloznaczność komunikowania polityków jego zdaniem wynika wprost z konieczności alokowania posiadanych zasobów (czasu, energii i pieniędzy), warunkowanej zarówno ograniczeniami po stronie nadawcy i odbiorcy komunikatów (wybiórczość kodowania i dekodowania, ograniczenia procesów percepcji, ale też magazynowania informacji w pamięci) ${ }^{22}$, jak i samego kanału komunikacyjnego (komunikowanie publiczne zawsze zapośredniczone, poprzez media) czy kontekstu (wypowiedzi innych polityków z własnej bądź przeciwnej opcji politycznej). Z natury rzeczy zakomunikowane mogą być więc jedynie wybrane problemy polityczne i jedynie niektóre propozycje ich rozwiązania - im mniej dookreślone, tym mniej podatne na wartościowanie i odrzucenie. Ponieważ badania wskazują jednoznacznie, iż szczegółowe propozycje programowe są stosunkowo mało efektywne w zdobywaniu poparcia wyborców, zaś sami wyborcy nierzadko nie są zainteresowani szczegółowymi komunikatami, których zrozumienie wymaga wysiłku i posiadania właściwego poziomu odniesienia (np. szczegółowej wiedzy w zakresie omawianego problemu, prawnej lub dziedziny gospodarki) ${ }^{23}$ - według Page’a politycy strategicznie wybierają niejasność wypowiedzi, zagospodarowując tym samym wolne zasoby poznawcze odbiorców wokół tematów ogólnych i łatwiej dostępnych procesom przetwarzania (preferowane będą więc takie kategorie, jak RODZINA i SPRAWIEDLIWOŚĆ, bardziej niż UNIA ENERGETYCZNA czy

${ }^{21}$ Cyt. za: tamże.

${ }^{22}$ Szczegółowy opis koncepcji B.I. Page’a czytelnik znajdzie w: W. Cwalina, dz. cyt.

${ }^{23}$ Por. P. Bull, Slippery..., ale także P. Bull, Slipperiness, evasion and ambiquity. Equivocation and facework in noncommittal political discourse, „Journal of Personality and Social Psychology” 2008, No. 27 (4) oraz P. Bull, K. Mayer, How to answer in polical interviews, „Political Psychology" 1993, No. 14 (4). 
REDUKCJA EMISJI GAZÓW). Co istotne, to właśnie dostępność poznawcza kategorii, nie zaś zróżnicowanie opinii $\mathrm{w}$ odniesieniu do nich ma - z punktu widzenia efektywności komunikacji - kluczowe znaczenie, albowiem im większe rozproszenie odbiorców w odniesieniu do poruszanego tematu, tym większa skuteczność wieloznacznych komunikatów ${ }^{24}$. Z drugiej strony, zdaniem Douglasa Waltona ${ }^{25}$, każda wieloznaczność powinna zostać w końcu rozwiązana, jeśli nie chcemy narazić się na utratę zaufania odbiorców (w związku z informacyjnym chaosem, powstałym w wyniku przypisywania tym samym kategoriom każdorazowo innego zakresu). I choć co do zasady wieloznaczność jako strategia komunikacyjna pomaga politykom zapobiec polaryzacji sądów (koncentracji wokół jednej, wyrazistej opinii), w sytuacji, w której oszczędność poznawcza uczestników komunikacji idzie $\mathrm{w}$ parze $\mathrm{z}$ ich brakiem wiedzy $\mathrm{w}$ zakresie komunikowanego problemu, sięganie po wieloznaczność zawsze wiąże się z ryzykiem zredukowania niedostępnych kategorii do poziomu ideologicznego (np. w sytuacji, gdy mowa jest o PAKIECIE KLIMATYCZNYM, a odbiorcom brak wystarczającej wiedzy np. w zakresie polityki energetycznej Unii Europejskiej, by ów pakiet ocenić). Wówczas komunikowanie poprzez poznawczą wieloznaczność, zamiast realizacji strategicznych lub wizerunkowych celów, służy przekonywaniu już przekonanych i nie pomaga przekonać nieprzekonanych.

Tabela 1. Analiza exposé Ewy Kopacz: zestawienie wyodrębnionych kategorii

\begin{tabular}{|c|c|c|}
\hline KATEGORIA & CENTRUM KATEGORII & EGZEMPLARZE KATEGORII \\
\hline \multirow{3}{*}{$\begin{array}{l}\text { SUKCES } \\
\text { NASZEGO } \\
\text { KRAJU }\end{array}$} & \multirow{3}{*}{$\begin{array}{c}\text { WYBÓR DONALDA } \\
\text { TUSKA NA } \\
\text { PRZEWODNICZĄCEGO } \\
\text { RADY EUROPEJSKIEJ }\end{array}$} & POLSKA W ZJDENOCZONEJ EUROPIE \\
\hline & & 7 LAT RZĄDÓW PLATFORMY \\
\hline & & NAJWIĘKSZY PO 89 ROKU \\
\hline \multirow{3}{*}{$\begin{array}{c}\text { DOBROBYT } \\
\text { POLSKI }\end{array}$} & \multirow{3}{*}{$\begin{array}{c}400 \text { MILARDÓW } \\
\text { ZŁOTYCH W NOWEJ } \\
\text { PERSPEKTYWIE } \\
\text { FINANSOWEJ }\end{array}$} & REKORDOWA KWOTA W HISTORII \\
\hline & & $\begin{array}{c}\text { WIĘKSZA SZANSA NIŻ } \\
\text { W POPRZEDNIEJ PERSPEKTYWIE } \\
\text { FINANSOWEJ }\end{array}$ \\
\hline & & $\begin{array}{c}\text { NAJWIĘKSZA SZANSZA W HISTORII } \\
\text { EUROPY ZACHODNIEJ PO II WOJNIE } \\
\text { ŚWIATOWEJ }\end{array}$ \\
\hline & & SOLIDARNOŚĆ Z UKRAINĄ \\
\hline
\end{tabular}

${ }^{24}$ Por. J.E. Cambell, Ambiguity in the issue positions of presidential candidates: A casual analysis, „American Journal of Political Science” 1983, No. 27 (2).

${ }^{25}$ Por. D. Walton, New dialectical rules for ambiguity, „Informal Logic” 2000, No. 20 (3). 


\begin{tabular}{|c|c|c|}
\hline KATEGORIA & CENTRUM KATEGORII & EGZEMPLARZE KATEGORII \\
\hline \multirow{9}{*}{$\begin{array}{c}\text { POLITYKA } \\
\text { ZAGRANICZNA }\end{array}$} & \multirow{9}{*}{$\begin{array}{l}\text { SYSTEM WARTOŚCI: } \\
\text { SOLIDARNOŚĆ } \\
\text { I JEDNOŚĆ W UE }\end{array}$} & $\begin{array}{c}\text { BRAK ZGODY NA ZABÓR } \\
\text { SUWERENNEGO TERYTORIUM } \\
\text { W EUROPIE }\end{array}$ \\
\hline & & $\begin{array}{c}\text { WSPARCIE DZIAŁAŃ } \\
\text { PROWOLNOŚCIOWYCH NA UKRAINIE }\end{array}$ \\
\hline & & SOLIDARNOŚĆ ENERGETYCZNA \\
\hline & & UNIA ENERGETYCZNA \\
\hline & & UKRÓCENIE MANIPULACJI \\
\hline & & CENOWYCH I PRAKTYK \\
\hline & & MONOPOLISTYCZNYCH \\
\hline & & $\begin{array}{c}\text { NOWE CELE REEDUKCJI EMISJI } \\
\text { GAZÓW }\end{array}$ \\
\hline & & $\begin{array}{c}\text { UMOWA O WOLNYM HANDLU UE } \\
\text { Z USA }\end{array}$ \\
\hline \multirow{6}{*}{$\begin{array}{l}\text { BEZPIECZEŃ- } \\
\text { STWO }\end{array}$} & \multirow{6}{*}{ WOJSKO } & $\begin{array}{l}\text { WZROST WYDATKÓW NA OBRONNOŚĆ } \\
\text { DO } 2 \% \text { PKB }\end{array}$ \\
\hline & & DODATKOWE 800 MLN ZŁ W 2016 ROKU \\
\hline & & NOWOCZESNY SPRZĘT DLA WOJSKA \\
\hline & & $\begin{array}{c}\text { KONSOLIDACJA POLSKIEGO } \\
\text { PRZEMYSŁU OBRONNEGO - POLSKA } \\
\text { GRUPA ZBROJENIOWA }\end{array}$ \\
\hline & & $\begin{array}{l}\text { CENTRUM WETERANA MISJI POZA } \\
\text { GRANICAMI KRAJU }\end{array}$ \\
\hline & & $\begin{array}{c}\text { INTERAKCJA Z POLICJĄ I STRAŻĄ } \\
\text { GRANICZNĄ }\end{array}$ \\
\hline \multirow{6}{*}{$\begin{array}{l}\text { FINANSE } \\
\text { PUBLICZNE }\end{array}$} & \multirow{6}{*}{ PODATKI } & $\begin{array}{c}\text { ODROCZENIE WEJŚCIA DO STREFY } \\
\text { EURO }\end{array}$ \\
\hline & & ZASADA $99 \%$ \\
\hline & & NOWA ORDYNACJA PODATKOWA \\
\hline & & SYSTEM E-PODATKI \\
\hline & & ASYSTENT PODATNIKA \\
\hline & & $\begin{array}{c}\text { BAZA WIEDZY ADMINISTRACJI } \\
\text { PODATKOWEJ }\end{array}$ \\
\hline
\end{tabular}




\begin{tabular}{|c|c|c|}
\hline KATEGORIA & CENTRUM KATEGORII & EGZEMPLARZE KATEGORII \\
\hline \multirow{10}{*}{$\begin{array}{c}\text { ZDROWA } \\
\text { GOSPODARKA }\end{array}$} & \multirow{10}{*}{ WSPARCIE INWESTYCJI } & KODEKS BUDOWALNY \\
\hline & & $\begin{array}{l}25 \text { MILIARDÓW ZE ŚRODKÓW BGK NA } \\
\text { KREDYTY DLA PRZEDSIĘBIORCÓW }\end{array}$ \\
\hline & & PROGRAM DE MINIMIS \\
\hline & & USTAWA ANTYKRYZYSOWA \\
\hline & & $\begin{array}{c}500 \text { MLN ZŁ Z FUNDUSZU } \\
\text { GWARANTOWANYCH ŚWIADCZEŃ } \\
\text { PRACOWNICZYCH }\end{array}$ \\
\hline & & $\begin{array}{l}\text { DOPŁATY DO WYNAGRODZEŃ LUB } \\
\text { SZKOLEŃ PRACOWNIKÓW }\end{array}$ \\
\hline & & $\begin{array}{l}\text { FUNDUSZ STABILIZACJI DOCHODÓW } \\
\text { ROLNICZYCH }\end{array}$ \\
\hline & & $\begin{array}{c}\text { RESTRUKTURYZACJA } \\
\text { I UNOWOCZEŚNIENIE GÓRNICTWA }\end{array}$ \\
\hline & & $\begin{array}{c}\text { KONCESJONOWANIE SPRZEDAŻY } \\
\text { ENERGII }\end{array}$ \\
\hline & & $\begin{array}{c}\text { ROZWÓJ NOWYCH TECHNOLOGII } \\
\text { WĘGLOWYCH }\end{array}$ \\
\hline \multirow{4}{*}{$\begin{array}{c}\text { KRYZYS DE- } \\
\text { MOGRAFICZNY }\end{array}$} & \multirow{4}{*}{ OPIEKA NAD DZIEĆMI } & $\begin{array}{c}\text { WIĘKSZE NAKŁADY NA BUDOWĘ } \\
\text { ŻŁOBKÓW }\end{array}$ \\
\hline & & $\begin{array}{c}\text { ULGI CIT PRZY TWORZENIU } \\
\text { PRZYZAKŁADOWYCH ŻŁOBKÓW } \\
\text { I PRZEDSZKOLI }\end{array}$ \\
\hline & & ŚWIADCZENIA RODZICIELSKIE \\
\hline & & ZASADA ZŁOTÓWKA ZA ZŁOTÓWKĘ \\
\hline \multirow{6}{*}{ SZKOŁA } & \multirow{6}{*}{$\begin{array}{c}\text { ZDROWIE } \\
\text { I BEZPIECZEŃSTWO }\end{array}$} & ŚMIECIOWE JEDZENIE \\
\hline & & MONITORING W SZKOŁACH \\
\hline & & BEZPŁATNY PODRĘCZNIK \\
\hline & & PROGRAM STAŻY DLA STUDENTÓW \\
\hline & & $\begin{array}{l}\text { STUDIA NA UCZELNIACH } \\
\text { ZAGRANICZNYCH }\end{array}$ \\
\hline & & $\begin{array}{c}\text { PROGRAM ODBUDOWY SZKOLNICTWA } \\
\text { ZAWODOWEGO }\end{array}$ \\
\hline
\end{tabular}




\begin{tabular}{|c|c|c|}
\hline KATEGORIA & CENTRUM KATEGORII & EGZEMPLARZE KATEGORII \\
\hline $\begin{array}{l}\text { ROZWÓJ } \\
\text { NAUKI }\end{array}$ & ? & WZROST FINANSOWANIA DO 2\% PKB \\
\hline \multirow{4}{*}{$\begin{array}{l}\text { TROSKA O } \\
\text { STARSZYCH }\end{array}$} & \multirow{4}{*}{$\begin{array}{c}\text { ZDROWIE } \\
\text { I BEZPIECZEŃSTWO }\end{array}$} & $\begin{array}{c}\text { INSTYTUCJE DZIENNYCH DOMÓW } \\
\text { OPIEKI }\end{array}$ \\
\hline & & WALORYZACJA EMERYTUT \\
\hline & & $\begin{array}{l}\text { PAKIET KOLEJKOWY } \\
\text { I ONKOLOGICZNY }\end{array}$ \\
\hline & & $\begin{array}{l}\text { FINANSOWANIE SPECJALIZACJI DLA } \\
\text { LEKARZY REZYDENTÓW }\end{array}$ \\
\hline \multirow{13}{*}{$\begin{array}{l}\text { INFRASTRUK- } \\
\text { TURA }\end{array}$} & \multirow{13}{*}{ DROGI I KOLEJ } & $\begin{array}{c}\text { W } 2014 \text { ROKU: } 160 \text { KM ODDANYCH } \\
\text { DRÓG EKSPRESOWYCH }\end{array}$ \\
\hline & & $\begin{array}{c}\text { W } 2014 \text { ROKU UMOWY NA } 300 \\
\text { KOLEJNYCH KM }\end{array}$ \\
\hline & & $\begin{array}{c}\text { W } 2015 \text { ROKU: } 250 \text { KM ODDANYCH } \\
\text { DRÓG EKSPRESOWYCH }\end{array}$ \\
\hline & & $\begin{array}{c}\text { W } 2015 \text { ROKU: UMOWY NA PONAD } \\
500 \text { KOLEJNYCH KM }\end{array}$ \\
\hline & & $\begin{array}{l}\text { W LATACH 2014-2020: BUDOWA } \\
1770 \text { KM AUTOSTRAD }\end{array}$ \\
\hline & & W LATACH 2014-2020: 35 OBWODNIC \\
\hline & & 93 MILIARDY ZŁ INWESTYCJI \\
\hline & & $\begin{array}{l}\text { PEŁNA SIEĆ AUTOSTRAD: A1, A2, A4 I } \\
\text { DRÓG EKSPRESOWYCH; S3, S5, S6, S7, } \\
\text { S8 I S17 }\end{array}$ \\
\hline & & GOTOWA OBWODNICA WARSZAWY \\
\hline & & $\begin{array}{c}\text { REGULACJA W PRZEWOZACH } \\
\text { PASAŻERSKICH NA KOLEI }\end{array}$ \\
\hline & & $\begin{array}{c}3 \text { GODZ. TRWA PODRÓŻ Z GDAŃSKA } \\
\text { DO WARSZAWY }\end{array}$ \\
\hline & & $\begin{array}{l}3 \text { GODZ. } 40 \text { MIN. TRWA PODRÓŻ } \\
\text { Z WROCŁAWIA DO WARSZAWY }\end{array}$ \\
\hline & & $\begin{array}{c}2 \text { GODZ. TRWA PODRÓŻ Z KRAKOWA } \\
\text { I KATOWIC DO WARSZAWY }\end{array}$ \\
\hline
\end{tabular}




\begin{tabular}{|c|c|c|}
\hline KATEGORIA & CENTRUM KATEGORII & EGZEMPLARZE KATEGORII \\
\hline & & $\begin{array}{l}\text { NOWE SKŁADY POCIĄGÓW } \\
\text { O WARTOŚCI } 6 \text { MLD ZŁ }\end{array}$ \\
\hline \multirow{2}{*}{$\begin{array}{l}\text { POTENCJAL } \\
\text { MORZA }\end{array}$} & \multirow{2}{*}{$\begin{array}{l}\text { MORZE JAKO OKNO } \\
\text { NA ŚWIAT }\end{array}$} & WIĘKSZA PRZEPUSTOWOŚĆ PORTÓW \\
\hline & & INWESTYCJA W INFRASTRUKTURĘ \\
\hline $\begin{array}{l}\text { REWOLUCJA } \\
\text { CYFROWA }\end{array}$ & $\begin{array}{l}\text { POWSZECHNOŚĆ } \\
\text { INTERNETU }\end{array}$ & $\begin{array}{l}\text { SYSTEM POWIADAMIANIA } \\
\text { O KLĘSKACH ŻYWIOŁOWYCH }\end{array}$ \\
\hline \multirow{5}{*}{ KULTURA } & \multirow{5}{*}{ DOSTĘPNA } & $\begin{array}{l}\text { TANSZE BILETY DO MUZEÓW } \\
\text { I TEATRÓW }\end{array}$ \\
\hline & & BOGATSZA OFERTA BIBLIOTEK \\
\hline & & $\begin{array}{l}\text { DARMOWE LEKCJE W INSTYTUCJACH } \\
\text { KULTURY }\end{array}$ \\
\hline & & $\begin{array}{c}\text { DARMOWY DOSTĘP PRZEZ INTERNET } \\
\text { DO KSIĄŻEK, NAGRAŃ KONCERTÓW } \\
\text { I SPEKTAKLI TEATRALNYCH }\end{array}$ \\
\hline & & $\begin{array}{c}\text { PROGRAM EDUKACYJNY DOTYCZĄCY } \\
\text { BUDOWANIA NOWOCZESNEGO } \\
\text { PATRIOTYZMU I ŚWIADOMOŚCI } \\
\text { HISTORYCZNEJ }\end{array}$ \\
\hline
\end{tabular}

Źródto: oprac. własne.

Tab. 2. Analiza exposé Beaty Szydło: zestawienie wyodrębnionych kategorii

\begin{tabular}{|c|c|c|c|}
\hline $\begin{array}{l}\text { AMALGAMAT } \\
\text { KONCEPTUALNY }\end{array}$ & KATEGORIA & $\begin{array}{c}\text { CENTRUM } \\
\text { KATEGORII }\end{array}$ & $\begin{array}{l}\text { EGZEMPLARZE } \\
\text { KATEGORII }\end{array}$ \\
\hline \multirow{4}{*}{$\begin{array}{l}\text { DOBRA } \\
\text { ZMIANA }\end{array}$} & \multirow{4}{*}{ ZMIANA } & \multirow{2}{*}{$\begin{array}{c}\text { SPOSOBU } \\
\text { SPRAWOWANIA } \\
\text { WŁADZY }\end{array}$} & $\begin{array}{c}\text { POKORA/PRACA/UMIAR/ } \\
\text { ROZTROPNOŚĆ }\end{array}$ \\
\hline & & & $\begin{array}{l}\text { KONIEC Z AROGANCJĄ } \\
\text { I PYCHĄ WŁADZY }\end{array}$ \\
\hline & & $\begin{array}{l}\text { ORGANIZACJI } \\
\text { RADY } \\
\text { MINISTRÓW }\end{array}$ & $\begin{array}{c}\text { POWOŁANIE NOWYCH } \\
\text { MINISTERSTW }\end{array}$ \\
\hline & & $\begin{array}{l}\text { DOTYCHCZASO- } \\
\text { WEJ POLITYKI }\end{array}$ & $\begin{array}{c}\text { OWOCE ROZWOJU DLA } \\
\text { WSZYSTKICH }\end{array}$ \\
\hline
\end{tabular}




\begin{tabular}{|c|c|c|c|}
\hline $\begin{array}{l}\text { AMALGAMAT } \\
\text { KONCEPTUALNY }\end{array}$ & KATEGORIA & $\begin{array}{l}\text { CENTRUM } \\
\text { KATEGORII }\end{array}$ & $\begin{array}{l}\text { EGZEMPLARZE } \\
\text { KATEGORII }\end{array}$ \\
\hline \multirow{9}{*}{$\begin{array}{c}\text { AKTYWIZACJA } \\
\text { WIELKIEJ } \\
\text { REZERWY }\end{array}$} & \multirow{9}{*}{ REZERWA } & \multirow{6}{*}{$\begin{array}{l}\text { KAPITAŁ } \\
\text { FINANSOWY }\end{array}$} & ŚRODKI EUROPEJSKIE \\
\hline & & & $\begin{array}{l}\text { ŚRODKI BANKÓW - } \\
\text { SYSTEM LTRO }\end{array}$ \\
\hline & & & \begin{tabular}{|c} 
OSZCZĘDNOŚCI \\
NA KONTACH \\
PRZEDSIĘBIORCÓW - \\
ZACHĘTY INWESTYCYJNE
\end{tabular} \\
\hline & & & UMOCNIENIE ROLI BGK \\
\hline & & & $\begin{array}{c}\text { POWOŁANIE „POLSKICH } \\
\text { INWESTYCJI” }\end{array}$ \\
\hline & & & $\begin{array}{l}\text { URUCHOMIENIE FUNDU- } \\
\text { SZU INWESTYCYJNEGO } \\
\text { PRZEDSIĘBIORSTW PAŃ- } \\
\text { STWOWYCH }\end{array}$ \\
\hline & & \multirow{3}{*}{$\begin{array}{c}\text { POTENCJAL } \\
\text { INTELEKTUALNY } \\
\text { POLAKÓW }\end{array}$} & $\begin{array}{c}\text { WSPÓŁPRACA NAUKI } \\
\text { Z BIZNESEM }\end{array}$ \\
\hline & & & $\begin{array}{l}\text { NARODOWE FORUM } \\
\text { PRZEDSIĘBIORCÓW }\end{array}$ \\
\hline & & & $\begin{array}{c}\text { SZKOLNICTWO } \\
\text { ZAWODOWE } \\
\text { DOSTOSOWANE DO } \\
\text { RZECZYWISTYCH } \\
\text { POTRZEB RYNKU PRACY }\end{array}$ \\
\hline \multirow{4}{*}{$\begin{array}{c}\text { AKTYWIZACJA } \\
\text { WIELKIEJ } \\
\text { REZERWY }\end{array}$} & \multirow{4}{*}{ REZERWA } & \multirow{4}{*}{$\begin{array}{l}\text { WSPARCIE PRZED- } \\
\text { SIĘBIORCZOŚCI }\end{array}$} & $\begin{array}{c}\text { OBNIŻKA CIT } \\
\text { DLA MAŁYCH } \\
\text { PRZEDSIĘBIORSTW }\end{array}$ \\
\hline & & & $\begin{array}{c}\text { LIKWIDACJA PRZESZKÓD } \\
\text { BIUROKRATYCZNYCH }\end{array}$ \\
\hline & & & $\begin{array}{c}\text { PODWÓJNY ODPIS } \\
\text { INWESTYCYJNY }\end{array}$ \\
\hline & & & $\begin{array}{l}\text { NARODOWE FORUM } \\
\text { PRZEDSIĘBIORCÓW }\end{array}$ \\
\hline
\end{tabular}




\begin{tabular}{|c|c|c|c|}
\hline $\begin{array}{l}\text { AMALGAMAT } \\
\text { KONCEPTUALNY }\end{array}$ & KATEGORIA & $\begin{array}{l}\text { CENTRUM } \\
\text { KATEGORII }\end{array}$ & $\begin{array}{l}\text { EGZEMPLARZE } \\
\text { KATEGORII }\end{array}$ \\
\hline \multirow{4}{*}{$\begin{array}{l}\text { WYZWANIA } \\
\text { PRZYSZŁOŚCI }\end{array}$} & \multirow{4}{*}{ WYZWANIA } & $\begin{array}{l}\text { WYRWAĆ SIĘ } \\
\text { Z PUŁAPKI } \\
\text { ŚREDNIEGO } \\
\text { ROZWOJU }\end{array}$ & $\begin{array}{l}\text { PRZYSPIESZYĆ TEMPO } \\
\text { WZROSTU }\end{array}$ \\
\hline & & \multirow{3}{*}{$\begin{array}{l}\text { PODSTAWA ROZ- } \\
\text { WOJU: INWESTY- } \\
\text { CJE I INNOWACJE }\end{array}$} & $\begin{array}{l}\text { REINDRUSTRIALIZACJA } \\
\text { KRAJU: PRZEMYSŁ ENER- } \\
\text { GETYCZNY, CHEMICZNY, } \\
\text { ZBROJENIOWY }\end{array}$ \\
\hline & & & $\begin{array}{l}\text { WZMOCNIENIE DOLINY } \\
\text { MLECZNEJ I LOTNICZEJ }\end{array}$ \\
\hline & & & $\begin{array}{l}\text { ROZBUDOWA ZAPLECZA } \\
\text { BADAWCZO-ROZWOJOWE- } \\
\text { GO NANO- I BIOTECHNO- } \\
\text { LOGII }\end{array}$ \\
\hline \multirow{6}{*}{$\begin{array}{l}\text { WYZWANIA } \\
\text { PRZYSZŁOŚCI }\end{array}$} & \multirow{6}{*}{$\begin{array}{l}\text { BEZPIECZEŃ- } \\
\text { STWO }\end{array}$} & \multirow{3}{*}{ MILITARNE } & $\begin{array}{l}\text { ROZBUDOWA SIŁ } \\
\text { ZBROJNYCH }\end{array}$ \\
\hline & & & $\begin{array}{l}\text { UMOCNIENIE WSCHOD- } \\
\text { NIEJ FLANKI NATO }\end{array}$ \\
\hline & & & USA JAKO GWARANT \\
\hline & & \multirow{3}{*}{ ENERGETYCZNE } & $\begin{array}{c}\text { GOSPODARKA OPARTA NA } \\
\text { WĘGLU }\end{array}$ \\
\hline & & & $\begin{array}{l}\text { ZAGWARANTOWANIE } \\
\text { DOSTAW ROPY I GAZU }\end{array}$ \\
\hline & & & ROZBUDOWA GAZOPORTU \\
\hline \multirow{5}{*}{$\begin{array}{l}\text { WYZWANIA } \\
\text { PRZYSZŁOŚCI }\end{array}$} & \multirow{5}{*}{$\begin{array}{l}\text { BEZPIECZEŃ- } \\
\text { STWO }\end{array}$} & \multirow{5}{*}{$\begin{array}{c}\text { POLITYKA } \\
\text { ZAGRANICZNA }\end{array}$} & POSTAWA „PODMIOTOWA” \\
\hline & & & $\begin{array}{c}\text { SOLIDARNOŚĆ } \\
\text { W NIESIENIU POMOCY } \\
\text { W SYTUACJACH } \\
\text { NADZWYCZAJNYCH }\end{array}$ \\
\hline & & & $\begin{array}{l}\text { DYPLOMACJA } \\
\text { EKONOMICZNA }\end{array}$ \\
\hline & & & KONTAKTY Z POLONIĄ \\
\hline & & & INTEGRACJA Z UE \\
\hline
\end{tabular}




\begin{tabular}{|c|c|c|c|}
\hline $\begin{array}{l}\text { AMALGAMAT } \\
\text { KONCEPTUALNY }\end{array}$ & KATEGORIA & $\begin{array}{l}\text { CENTRUM } \\
\text { KATEGORII }\end{array}$ & $\begin{array}{l}\text { EGZEMPLARZE } \\
\text { KATEGORII }\end{array}$ \\
\hline \multirow{9}{*}{$\begin{array}{l}\text { WYZWANIA } \\
\text { PRZYSZŁOŚCI }\end{array}$} & \multirow[t]{2}{*}{ RODZINA } & \multirow[t]{2}{*}{ PRACA } & $\begin{array}{c}\text { PLAN TWORZENIA } \\
\text { WIELKIEJ ILOŚCI NOWYCH } \\
\text { MIEJSC PRACY }\end{array}$ \\
\hline & & & $\begin{array}{l}\text { ROZBUDOWA SIECI } \\
\text { PRZEDSZKOLI }\end{array}$ \\
\hline & \multirow{7}{*}{ RODZINA } & \multirow{3}{*}{ PŁACA } & $\begin{array}{c}\text { PAKT O PODNIESIENIU } \\
\text { PŁAC }\end{array}$ \\
\hline & & & $\begin{array}{l}\text { LIKWIDACJA UMÓW } \\
\text { ŚMIECIOWYCH }\end{array}$ \\
\hline & & & $\begin{array}{c}\text { ZWIĘKSZENIE POPYTU } \\
\text { NA PRACĘ }\end{array}$ \\
\hline & & MIESZKANIA & $\begin{array}{c}\text { TANIE MIESZKANIA NA } \\
\text { DZIAŁKACH NALEŻĄ- } \\
\text { CYCH DO PAŃSTWA }\end{array}$ \\
\hline & & \multirow{3}{*}{$\begin{array}{c}\text { OPIEKA } \\
\text { ZDROWOTNA }\end{array}$} & $\begin{array}{c}\text { EKONOMIZACJA } \\
\text { PUBLICZNEJ SŁUŻBY } \\
\text { ZDROWIA }\end{array}$ \\
\hline & & & $\begin{array}{l}\text { ZMIANA FUNKCJI } \\
\text { LEKARZY }\end{array}$ \\
\hline & & & $\begin{array}{c}\text { PROGRAM TWORZENIA } \\
\text { GABINETÓW } \\
\text { STOMATOLOGICZNYCH } \\
\text { I LEKARSKICH } \\
\text { W SZKOŁACH }\end{array}$ \\
\hline \multirow{4}{*}{$\begin{array}{l}\text { WYZWANIA } \\
\text { PRZYSZŁOŚCI }\end{array}$} & \multirow{4}{*}{$\begin{array}{l}\text { SPRAWIEDLI- } \\
\text { WOŚĆ }\end{array}$} & \multirow{4}{*}{$\begin{array}{l}\text { ŚĄDOWNICTWO } \\
\text { (NIESPRAWIEDLI- } \\
\text { WE) }\end{array}$} & $\begin{array}{l}\text { BIEDNI BEZ WSPARCIA } \\
\text { KANCELARII } \\
\text { ADWOKACKICH }\end{array}$ \\
\hline & & & $\begin{array}{c}\text { PŁATNICY PODATKÓW } \\
\text { SROGO KARANI ZA } \\
\text { NIEUWAGĘ }\end{array}$ \\
\hline & & & $\begin{array}{l}\text { DZIECI ODBIERANE } \\
\text { RODZICOM }\end{array}$ \\
\hline & & & $\begin{array}{l}\text { NISKA EFEKTYWNOŚĆ } \\
\text { I KORUPCJA }\end{array}$ \\
\hline
\end{tabular}




\begin{tabular}{|c|c|c|c|}
\hline $\begin{array}{l}\text { AMALGAMAT } \\
\text { KONCEPTUALNY }\end{array}$ & KATEGORIA & $\begin{array}{c}\text { CENTRUM } \\
\text { KATEGORII }\end{array}$ & $\begin{array}{l}\text { EGZEMPLARZE } \\
\text { KATEGORII }\end{array}$ \\
\hline \multirow{5}{*}{$\begin{array}{l}\text { WYZWANIA } \\
\text { PRZYSZŁOŚCI }\end{array}$} & \multirow{5}{*}{$\begin{array}{l}\text { SPRAWIEDLI- } \\
\text { WOŚĆ }\end{array}$} & \multirow{5}{*}{$\begin{array}{c}\text { SPOŁECZNA } \\
\text { (WYRÓWNANIE } \\
\text { SZANS) }\end{array}$} & $\begin{array}{c}\text { SPOŁECZNE WYZWANIA } \\
\text { (MIEJSCA, W KTÓRYCH } \\
\text { PROWADZONA BĘDZIE } \\
\text { REWITALIZACJA } \\
\text { I RENOWACJA) }\end{array}$ \\
\hline & & & $\begin{array}{c}\text { PROJEKT UBEZPIECZEŃ } \\
\text { ROLNICZYCH }\end{array}$ \\
\hline & & & $\begin{array}{c}\text { OCHRONA ZIEMI PRZED } \\
\text { WYKUPEM }\end{array}$ \\
\hline & & & $\begin{array}{c}\text { WYRÓWNANIE DOPŁAT } \\
\text { DLA ROLNIKÓW } \\
\text { (W STOSUNKU DO UE) }\end{array}$ \\
\hline & & & $\begin{array}{l}\text { SZANSE EDUKACYJNE } \\
\text { DZIECI WIEJSKICH } \\
\text { (ZWIJANIE SZKÓŁ) }\end{array}$ \\
\hline
\end{tabular}

\section{Bibliografia}

Bull P., Mayer K., How to answer in polical interviews, „Political Psychology” 1993, No. 14 (4), pp. 651-666.

Bull P., Slipperiness, evasion and ambiquity. Equivocation and facework in noncommittal political discourse, ,Journal of Personality and Social Psychology” 2008, No. 27 (4), pp. 333-344.

Bull P., Slippery politicians?, „The Psychologist” 2003, No. 16 (11), pp. 592-595.

Cambell J.E., Ambiguity in the issue positions of presidential candidates: A casual analysis, „American Journal of Political Science” 1983, No. 27 (2), pp. 284-293.

Cwalina W., Wieloznaczność poznawcza w komunikacji, [w:] Psychologia poznawcza w praktyce. Ekonomia, biznes, polityka, red. A. Falkowski, T. Zaleśkiewicz, PWN, Warszawa 2012, s. 187-261.

Fauconnier G., Turner M., Tworzenie amalgamatów jako jeden z głównych procesów w gramatyce, tłum. W. Kubasiński, D. Stanulewicz, [w:] Językoznawstwo kognitywne II. Zjawiska pragmatyczne, red. Kubasiński, D. Stanulewicz, Gdańsk 2001, s. 32-48.

Graeser A.C., Millis K.K., Zwaan R.A., Discourse comprehension, „Annual Review of Psychology" 1997, 48, pp. 162-189.

Kardela H., (Nie)podobieństwo w morfologii. Amalgamaty kognitywne, [w:] Kognitywistyka. Podobieństwo, red. H. Kardela, Z. Muszyński, M. Rajewski, Wydawnictwo UMCS, Lublin 2006, s. 195-211.

Maruszewski T., Psychologia poznania, GWP, Gdańsk 2001.

Walton D., New dialectical rules for ambiguity, „Informal Logic” 2000, No. 20 (3), pp. 261-274. https://www.premier.gov.pl/expose-premier-beaty-szydlo-stenogram.html [dostęp: 1.03.2016]. 
Karolina Dobrosz-Michiewicz

The structure of ambiguity phenomena (based on cognitive analyses of political communications)

(Summary)

The paper presents ambiguity phenomena in terms of cognitive categorization and blending processes. Politicians' manifesto speeches are analysed based on Lakoff's and Langacker's semantics and Langacker's grammar research investigation, resulting in describing ambiguity phenomena more as the sender's or receiver's mental concepts than as a linguistic property of the message. Moreover, cognitive points of view in the research on ambiguity reveals its multileveled nature due to the polysemic nature of mental categories or blends.

Keywords: ambiguity cognitive phenomena, mental categorization, cognitive grammar, cognitive semantics, multileveled ambiguity. 